\title{
Problematising the Ultimate Other of Modernity: the Crystallisation of Coloniality in International Politics
}

\author{
Ramon Blanco* \\ Ana Carolina Teixeira Delgado**
}

\begin{abstract}
This article examines a key element of the power relations underpinning international politics, namely coloniality. It delineates the coloniality of international politics, and elucidates the fundamental aspects of its operationalisation on the one hand, and its crystallisation into international politics on the other. The article is structured into three sections. First, it explores the meaning of coloniality, and outlines its fundamental characteristics. Next, it delineates a crucial operative element of coloniality, the idea of race, and the double movement through which coloniality is rendered operational - the colonisation of time and space. Finally, the article analyses two structuring problematisations that were fundamental to the crystallisation of coloniality in international politics - the work of Francisco de Vitoria, and the Valladolid Debate. It argues that the way in which these problematisations framed the relationship between the European Self and the ultimate Other of Western modernity - the indigenous peoples in the Americas - crystallised the pervasive role of coloniality in international politics.
\end{abstract}

Keywords: coloniality; international politics; colonial matrix of power; race; Francisco de Vitoria; Valladolid Debate.

\section{Introduction}

In recent decades, the discipline of International Relations (IR) has gone through a widening diversification process. While previous analyses were underpinned by different strands of Liberalism, Realism or, to a lesser degree, Marxism, from the late 1980s onwards the discipline opened itself to new forms of theorisation, including Constructivism,

\footnotetext{
* Federal University of Latin American Integration (UNILA), Foz do Iguacu-PR, Brazil; blanco.ramon@ gmail.com. ORCID iD 0000-0003-0330-6235.

** Federal University of Latin American Integration (UNILA), Foz do Iguacu-PR, Brazil; acaroldelgado@ yahoo.com.br. ORCID iD 0000-0003-3297-7249.
} 
Feminism, Post-Structuralism and Post-Colonialism, to name a few. As a result, IR has become far more plural, not only in respect of the epistemological and ontological issues advanced by these approaches, but also in respect of the realities that have emerged from their critiques of the discipline's exclusionary character.

Nevertheless, many of the analyses of the deep-seated and hierarchical power relations at work in international politics remain limited. This occurs mainly because such critiques, while denouncing various forms of power relations, or even criticising Eurocentrism, still privilege Eurocentric thinkers such as Michel Foucault, Antonio Gramsci and Jacques Derrida, among many others. They still advance what Ramón Grosfoguel (2007: 211) calls 'a Eurocentric critique of eurocentrism', pushing a fundamental aspect of international reality - the entrenched coloniality of international politics - into invisibility.

There is little novelty in connecting coloniality and international politics. ${ }^{1}$ Nonetheless, some aspects of this connection need further clarification. Consequently, the purpose of this article is not merely to draw attention to the notion of coloniality and to delineate its characteristics. Most importantly, it elucidates a fundamental aspect of the crystallisation of coloniality in international politics. By reframing the departure point from where the international is usually discussed, the article brings to the core of the discussion about international politics the indigenous peoples of the Americas. More specifically, it draws attention to two fundamental problematisations that, through the very manner in which they framed the relationship between the European Self and the Amerindian Other, crystallised coloniality in international politics. These problematisations are the thoughts of Francisco de Vitoria and of Bartolomé de Las Casas and Juan Gines de Sepulveda, protagonists of the Valladolid Debate. Their thoughts constitute the early dawn of Western modernity (Dussel 1993, 2013). Given the depth of their enquiries - exploring the very limits of humanness and humanity - they placed Amerindians in the position of the ultimate Other of modernity. Remarkably, although these problematisations are not completely unknown to the discipline of IR (see Jahn 2000; Inayatullah and Blaney 2004; Inayatullah 2008; Boucher 2009; Hudson 2009; Ortega 2016), their role in the crystallisation of coloniality in international politics has still not been adequately explored. This is the main purpose of this article.

The article is divided in three sections. In the first section, it discusses the notion of coloniality, stressing its differences from colonialism, and outlining its fundamental characteristics and dimensions. Next, in the second section, the paper delineates a crucial operative element of coloniality and the double movement through which coloniality is operationalised. This section starts by examining the idea of race as a key element of social classification and hierarchy, which underpins the operationalisation of coloniality internationally. Then, the article evinces that coloniality establishes itself as a double colonisation, namely the colonisation of time and space. Finally, in the third section, the article analyses two structuring problematisations that were fundamental to the crystallisation of coloniality in international politics. It delineates the thoughts of Francisco de Vitoria and the participants in the Valladolid Debate, by evincing that the manner in which they problematise the relationship between the European Self and the ultimate Other of West- 
ern modernity - the indigenous people in the Americas - is essential to the crystallisation of coloniality internationally.

\section{What is coloniality?}

Due to its marginality in the discipline, coloniality is still widely regarded as a mere synonym for colonialism or, to a lesser degree, neocolonialism. In fact, all these terms are related to closely interwoven sets of power relations, and it could also be argued that coloniality has emerged from the colonial relationships of the past. Nevertheless, they do embody different practical processes and theoretical concerns. Therefore, before exploring the link between coloniality and international politics, it is prudent to distinguish coloniality from colonialism and neocolonialism (see, for instance, Young 2001, chapters 2 and 4$)$.

On the one hand, colonialism stands out as a crucial phenomenon related to the exercise of power in the colonial world (see, for instance, Césaire 2000; Chabrabarty 2008; Chaterjee 1993; Fanon 2004; Young 2001). According to Nelson Maldonado-Torres (2007: 243), '[c]olonialism denotes a political and economic relation in which the sovereignty of a nation or a people rests on the power of another nation, which makes such nation an empire.' In this kind of relationship, it is clearly perceptible that they form 'a bounded geographical entity' (Bush 2006: 2). In political terms, this is a 'relationship of domination and subordination between one polity (called the metropole) and one or more territories (called colonies) that lie outside the metropole's boundaries, yet are claimed as its lawful possessions' (Abernethy 2000: 19).

It is true that colonialism is a kind of power relation that would entail not just a material aspect. For Albert Memmi (1991) and Ashis Nandy (1983), colonialism also has a subjective aspect, namely the formation of the identities that reproduce the inferioritysuperiority divide intrinsic to colonial logics. However, it should be borne in mind that colonialism necessarily rests on the possession of the territory of the Other. Over time, the need to control such territory became more flexible and even unnecessary, leading to neocolonialism. This is because, somewhat paradoxically, 'the state which is subject to it is, in theory, independent and has all the outward trappings of international sovereignty. In reality, its economic system and thus political policy is directed from outside' (Nkrumah 1965: ix). Therefore, under neocolonialism, dominant international interests are operationalised 'by informal means if possible, or by formal annexations [only] when necessary' (Gallagher and Robinson 1953: 3).

On the other hand, coloniality, a concept advanced by the Peruvian sociologist Aníbal Quijano (1992a, 2007), seeks to make sense of a hierarchical power structure - a 'colonial power matrix' and the 'coloniality of power' in Quijano's words - that was designed and developed in the colonial era and remains active internationally. Moreover, it is clear that coloniality 'emerges from a particular socio-historical setting, that of the discovery and conquest of the Americas' (Maldonado-Torres 2007: 243). Quijano (2007: 168) states categorically that ' $[\mathrm{w}] \mathrm{ith}$ the conquest of the societies and the cultures which inhabit what 
today is called Latin America, began the constitution of a new world order, culminating, five hundred years later, in a global power covering the whole planet.'

Therefore, rather than referring exclusively to the domination of a certain territory, coloniality 'refers to long-standing patterns of power that emerged as a result of colonialism, but that define culture, labour, intersubjective relations, and knowledge production well beyond the strict limits of colonial administrations' (Maldonado-Torres 2007: 243). Consequently, it can be understood as a power system, both symbolic and practical, that has not ceased with the end of colonialism. On the contrary, coloniality is still operative internationally, even though colonial administrations have been almost entirely eradicated globally. Therefore, coloniality 'allows us to understand the continuity of colonial forms of domination after the end of colonial administrations' (Grosfoguel 2007: 219). Luciana Ballestrin (2013: 99) adds that the concept 'expresses a simple fact, that is, that the relationships of coloniality in the economic and political spheres did not end with the destruction of colonialism.'

Most importantly, the enduring feature of the coloniality of power manifests itself beyond the political and the economic dimension. As a result, the notion of coloniality seeks to capture and uncover different dimensions and layers where power is operationalised. Collectively, these dimension and layers form a colonial power matrix (Quijano 1992a, 2000a). As noted by Walter Mignolo (2010: 12), this colonial power matrix is 'a complex structure of intertwined levels' that form a symbolic and practical power structure composed by spheres such as: (1) the control of the economy; (2) the control of authority; (3) the control of the environment and natural resources; (4) the control of gender and sexuality; and (5) the control of subjectivity and knowledge. In this sense, this colonial power matrix encompasses multiple dimensions of life itself and all dimensions of the very existence.

As noted previously, this colonial power matrix emerged with the conquest of the Americas (Quijano 2000a). In order to gain a clearer picture of this process, one has to view the European colonial expansion from a different angle. This is exactly what Ramón Grosfoguel (2007: 215) does. He argues that, because the European colonial expansion is usually interpreted from a Eurocentric point of view, it creates the impression that such process is a result of the competition among European Empires, centred on an economic logic (Grosfoguel 2007: 215). While acknowledging the importance of this perspective, Grosfoguel (2007: 215) also argues that it promotes a narrow understanding of the colonial process, favouring the economic dimension at the cost of others, to the point of obliterating them entirely. In an effort to illuminate those dimensions, Grosfoguel performs an epistemic shift and puts himself in the place of an indigenous woman living in the Americas. Consequently, the picture changes dramatically. By making this epistemic shift, Grosfoguel argues that what 'arrived' in the Americas was not merely an economic system, but a 'broader and wider entangled power structure that an economic reductionist perspective of the word-system is unable to account for' (Grosfoguel 2007: 216). Observing the process from a different epistemic position, as Grosfoguel does, one perceives that what arrived in the Americas was a '[e]uropean/capitalist/military/christian/patriarchal/ 
white/heterosexual/male, who established 'several entangled global hierarchies' (Grosfoguel 2007: 216).

Therefore, rather than viewing the European colonial expansion in a one-dimensional manner, from a Eurocentric perspective, and centred on economics, this kind of shift broadens the understanding of this process, and shows that the colonial power matrix has numerous other dimensions. Grosfoguel (2007: 217) describes these as 'multiple and heterogeneous global hierarchies ("heterarchies") of sexual, political, epistemic, economic, spiritual, linguistic and racial forms of domination and exploitation.' In this colonial power matrix, 'it is the racial/ethnic hierarchy of the European/non-European divide [that] transversally reconfigures all of the other global power structures' (Grosfoguel 2007: 217). Given this perspective, it is important to shed greater light on the operative elements and characteristics of this power matrix.

\section{Race as an operative element and coloniality's double movement}

According to Walter Mignolo (2000: 17), the elements required to maintain the colonial power matrix are: (1) the (re)classification of the entire global population; (2) 'an institutional structure functional to articulate and manage such classifications (state apparatus, universities, church, etc)'; (3) 'the definition of spaces appropriate to such goals'; and (4) 'an epistemological perspective from which to articulate the meaning and profile of the new matrix of power and from which the new production of knowledge could be channelled.' In that sense, Quijano (2007: 168) argues that, while establishing colonial relations, Europeans produced the specific social discriminations that were later codified as 'racial,' 'ethnic,' 'anthropological' or 'national,' according to the times, agents and populations involved. Moreover, he notes ' $\mathrm{t}$ ] hese intersubjective constructions, product of Eurocentered colonial domination were even assumed to be 'objective, 'scientific', categories' (Quijano 2007: 168). Therefore, these various forms of social discrimination were, and remain, essential for the maintenance and operationalisation of colonial power matrix.

A fundamental pillar of the operationalisation of the coloniality of power, as Quijano (2000b) argues, rests in the notions of race and racism (see Quijano 1992b; Marks 1994: chapters 3,4 and 6). ${ }^{2}$ For him, the coloniality of power was conceived with the 'social category of "race" as the key element of the social classification of colonized and colonizers' (Quijano 2007: 171). As expected, '[a] characteristic feature of this type of social classification is that the relation between the subjects is not horizontal but vertical in character' (Maldonado-Torres 2007: 244). Quijano (2000b: 534) argues that the idea of race was 'originated in reference to phenotypic differences between conquerors and conquered.' Nevertheless, this phonotypical trait was soon 'constructed to refer to the supposed differential biological structures between those groups' (Quijano 2000b: 534). Therefore, coloniality is based on the 'codification of the differences between conquerors and conquered in the idea of "race" (sic) a supposedly different biological structure that placed some in a natural situation of inferiority to the others' (Quijano 2000b: 533). For him, '[t]he conquistadors assumed this idea as the constitutive, founding element of the relations of 
domination that the conquest imposed.' Consequently, race became the fundamental axis of colonial social relations, determining its hierarchies and social roles. As Quijano (2007: 534) points out, '[a]s time went by, the colonizers codified the phenotypic trait of the colonized as color, and they assumed it as the emblematic characteristic of racial category.'

This biological conception of race in no way excludes its cultural and symbolic components as fundamental instruments of coloniality. Indeed, several analysis of different Latin American societies have pointed out that race has also been operationalised in cultural domains, which are often overshadowed by the emphasis on biology (see, for instance, De La Cadena 2000; Twinam 2009). In fact, the societal division in Spanish-America was largely forged through the transposition and rereading of the codes of Spanish society, which were linked to religion as a political factor. This explains, for instance, that the 'Limpieza de Sangre' (blood purification) - applicable to non-Christians and aimed at their conversion and purification - in Latin America mirrored efforts to obtain 'Gracias al Sacar' in Spanish society. This was a royal certification that, at least in theory, made it possible for Mestizos, descended from the Spanish or the Criollo, to become white.

According to Castro-Gómez (2010: 18), being white in a colonial society was not restricted to the issue of phenotype. It was related, above all, to the 'enactment of a device woven from religious beliefs, types of clothing, certifications of nobility, behaviors and [...] ways of producing knowledge.' In his view, it was a 'lifestyle' primarily associated with the figures of the Spaniard and the Criollo that served as a parameter for social classification on the one hand, and for distinguishing, for instance, those who held positions in the colonial administration, enjoyed privileges, and were wealthy on the other (Castro-Gómez 2010: 18). Thus, 'being white' denoted more than mere prestige in the colonial world. Most importantly, it was a sign of power that ensured the consolidation of social status and a series of prerogatives that were denied to Mestizos, even if they were relatively wealthy. Therefore, the whitening process - which started in the second half of the $18^{\text {th }}$ century in certain places in the Spanish America, including Nueva Granada, but also elsewhere - represented a colonial power strategy by the mixed-race or Mestizo population. Consequently, the overlapping of practical and daily elements on the one hand, and phenotypical and cultural symbols on the other, resulted in a situation where race was the crucial operative element in constituting and strengthening the colonial difference (Castro-Gómez 2010: chapter 2).

As European colonialism expanded, the idea of race became naturalised in respect of the 'colonial relations between Europeans and non-Europeans' (Quijano 2000b: 535). However, social classification was not restricted to the 'racial' aspect of the colonial relationship, and Quijano (2007: 171) argues that the 'coloniality of power is not exhausted in the problem of "racist" social relations.' In fact, the idea of race and racism 'becomes the organizing principle that structures all of the multiple hierarchies of the world-system [...] [it] organizes the world's population into a hierarchical order of superior and inferior people' (Grosfoguel 2007: 217), also in cultural terms. Consequently, race, as an essential aspect and operative element of coloniality (Quijano 2007: 171), becomes the 'fundamental criterion for the distribution of the world population into ranks, places and roles' in the international power structure (Quijano 2000b: 535). 
Based on this kind of understanding, one can move towards the analytical feature of the notion of coloniality (Mignolo 2010: 13-14). When the coloniality of power becomes a fundamental analytical element, it changes the way in which one frames and analyses several other issues. Thus, for Mignolo (2010: 14), 'the concept of coloniality opened the reconstruction and the restitution of silenced histories, repressed subjectivities and subalternized knowledges.' Indeed, it allows a reassessment of the international system, which obviously has a significant impact on conceptions of international relations. Mignolo (2000: 37), for instance, argues in favour of shifting one's analysis from a 'modern world' perspective to a 'modern/colonial world' one. For him, '[o]nce the coloniality of power is introduced into the analysis, the "colonial difference" becomes visible, and the epistemological fractures between the Eurocentric critique of Eurocentrism is distinguished from the critique of Eurocentrism, anchored in the colonial experience' (Mignolo 2000: 37).

This changes the very way in which modernity itself is problematised, which is highly significant since it draws the attention to dynamics that are still at work in current international politics. In its most widespread understanding, modernity has little, or even nothing, to do with the colonial experience in the Americas. As Maldonado-Torres (2007: 244) argues, modernity is 'usually considered to be a product of the European Renaissance or the European Enlightenment.' However, the notion of coloniality helps one to understand that, on the contrary, coloniality and modernity are intertwined. Mignolo (2009) argues, for instance, that coloniality is the darker side of modernity. In fact, modernity not only 'carries on its shoulders the heavy weight and responsibility of coloniality' (Mignolo 2000: 37), but also this 'model of power is at the heart of the modern experience' (Maldonado-Torres 2007: 244). Indeed, '[m] odernity as a discourse and as a practice would not be possible without coloniality, and coloniality continues to be an inevitable outcome of modern discourses' (Maldonado-Torres 2007: 244).

To understand this, one needs to take a small step back and, following Naeem Inayatullah and David Blaney (2004: 9), introduce Mary Pratt's (1992) idea of a 'contact zone' while making sense of the conquest of the Americas. For Pratt, the contact zone entails 'the spatial and temporal co-presence of subjects previously separated by geographic and historical disjunctures, and whose trajectories now intersect' (Pratt 1992: 6-7). Moreover, Inayatullah and Blaney (2004: 9) rightly argue that 'the historical experience is that these intersecting trajectories have been infused with inequalities of power; that is, the contact zone has generally become a "space of colonial encounters." Problematising modernity from a coloniality standpoint, one starts to perceive both as different sides of the same coin (Mignolo 2009: 42). Consequently, it becomes clear that both modernity and coloniality establish themselves in a double colonisation - of time $^{3}$ and of space (Mignolo $^{4}$ 2009: 42).

It is only when coloniality is placed at the centre of the analysis that these core features become visible. In Mignolo's (2009) view, whereas the colonisation of time is best represented by the 'invention of the Middle Age in the process of conceptualizing the Renaissance,' the colonisation of space was operationalised by the 'colonisation and conquest of the New World' (Mignolo 2009: 41-42). A fundamental feature of the colonisation of time is the temporalisation of difference ${ }^{5}$ (Helliwell and Hindess 2005). This means that the 
relationship between the 'Self' and the 'Other' is permanently problematised in terms of a temporal marker constructed by the Self towards the Other. Consequently, their relationship is developed in temporal terms defined by the Self, either allowing or denying the coevalness of the Other. Whereas the former means that the Other is placed in the same time as the Self, the latter, the denial of coevalness, following Johannes Fabian (1983), means the 'persistent and systematic tendency to place the referents [of a certain discourse] [...] in a Time other than the present of the producer of [this particular discourse]' (Fabian 1983: 31). Usually, they are placed in the past. As a result, the Other is placed on a linear and teleological timeline and is readily portrayed, for instance, as 'before,' 'the past,' 'less advanced,' 'backwards,' and so on, leading to an inferior position in a hierarchical structure of power.

As regards the colonisation of space, perhaps the very first picture that comes to one's mind, quite correctly, is the brutality and violence of the process, which is its most obvious dimension. However, the process also encompasses other elements that are less immediately evident. Tzvetan Todorov (1984) discussed them in his analysis of the conquest of America. Specifically, he identified two structural elements in Christopher Colombus's attitude towards Amerindians. In Todorov's perspective, Colombus: (1) either conceives the American population 'as human beings altogether, having the same right as himself; but then he sees them not only as equals but as identical, and this behavior leads to assimilationism (sic), the projection of his own values on the others'; or (2) he 'starts from the difference, but the latter is immediately translated into terms of superiority and inferiority (in his case, obviously, it is the Indians who are inferior)' (Todorov 1984: 42).

Therefore, the colonial contact zone, as in Inayatullah and Blaney's (2004) view, results in a 'double movement' towards difference and the Other that is underpinned by the systematic denial of coevalness of the latter, which is essential to coloniality in international politics. In this double movement, '[o]n the one hand, difference is recognized but constituted as degenerate, inferior or utterly other' (Inayatullah and Blaney 2004: 106). In this first movement, therefore, difference is rationalised in terms of superiority/inferiority, which justifies 'the subjection of the other to exploitation, physical eradication, social exclusion and/or systematic efforts to reform.' On the other hand, the second movement is based on 'a failure to recognize difference.' In this case, the ' $\mathrm{t}$ ] he other is interpreted as developmentally prior self, who, after tutelage, can become fully Christian, civilized or developed' (2004: 106). Hence, in this double movement, 'difference becomes inferiority, and the possibility of a common humanity requires assimilation' (Inayatullah and Blaney 2004: 10). Todorov (1984: 42-43) regards these elements as 'both grounded in egocentrism, in the identification of our own values [Colombus' in this case] with values in general, of our I with the universe - in the conviction that the world is one.' Rather than being confined to the past, he argues that this kind of attitude towards difference 'we shall find again in the following century and, in practice, down to our own day in every colonist in his relation to the colonized' (Todorov 1984: 42).

It is precisely resting on the aforementioned double colonisation and through the operationalisation of these two movements towards difference that coloniality functions and it is rendered operational in international politics. Given that the emergence of colo- 
niality is connected to the conquest of the Americas, it is not surprising that the double movement towards difference at the core of coloniality also has the conquest of Americas as a fundamental axis. Consequently, it is precisely through the very manner in which two structural problematisations frame the relationship between the European Self and the ultimate Other of modernity, the Amerindians, that coloniality becomes crystallised in international politics. It is towards the delineation of these two structural problematisations that this article now turns.

\section{The crystallisation of coloniality in international politics}

As already mentioned, a fundamental consequence of bringing coloniality to the core of the analysis is to problematise key issues differently and to understand the other side, very often marginalised and silenced, of some fundamental elements and processes of the international reality. Consequently, in addition to the colonisation of the Americas per se, one perceives two structuring problematisations that, precisely because they have as their core the relationship between the European Self and the Amerindian Other, and due to the very manner in which they frame this relationship, they are emblematic symbols of the functioning of the aforementioned double movement in international politics. Consequently, they are essential elements of the crystallisation of coloniality in international politics. They are: (1) the thought of Francisco de Vitoria in the very early stages of international law; and (2) the well-known Valladolid Debate (1550-1551).

With regard to the first structuring problematisation, a fundamental axis of the international reality where the double moment aforementioned is evident is, for instance, international law. With the notion of coloniality in mind, one can clearly perceive the 'colonial origins of international law' (Anghie 1996, 2004). Anthony Anghie goes on to argue that international law 'did not precede and thereby effortlessly resolve the problem of Spanish-Indian relations; rather, international law was created out of the unique issues generated by the encounter between the Spanish and the Indians' (Anghie 1996: 322, emphasis in the original).

In order to perceive it, one should analyse the early stages of the discipline of international law. The work of Hugo Grotius is commonly regarded as the beginning of international law. However, upon closer examination, one can trace the primitive stages of the discipline back to its Spanish heritage, and the work of de Francisco de Vitoria (1991) in particular (Kennedy 1986; Scott 2013; Anghie 1996: 321). In Mignolo's (2009: 46) view, Vitoria's treatise entitled On The American Indians 'is considered foundational in the discipline.' Usually, Vitoria's thought is understood as an effort to extend and apply 'existing juridical doctrines developed in Europe to determine the legal status of the Indians' (Anghie 1996: 322). However, in Anghie's understanding, Vitoria 'reconceptualizes these doctrines, or else invents new ones in order to deal with the novel problem of the Indians.' For him, the challenge that Vitoria sought to address was 'creating a system of law which could be used to account for relations between societies which he understood to belong to two very different cultural orders, each with its own ideas of propriety and governance' (Anghie 1996: 322). 
In order to advance his problematisation, Vitoria firstly criticised the framework in which the Spanish-Amerindian relationship was usually thought. As could be expected, this framework was developed by the Holy Roman Church, in order to deal with the Saracens, and essentially rested on two premises: (1) that human relations were governed by divine law; and (2) that the Pope, given his divine mission of spreading Christianity throughout the world, had universal jurisdiction (Anghie 1996: 323). Vitoria criticised both assumptions, and, in the process of doing so, outlined the basis for a new framework of international law, displacing it from the sphere of divine law to that of natural law. As Anghie (1996: 324) argues, Francisco de Vitoria (1991) starts outlining his framework by questioning whether the Amerindians, whom Vitoria refers to as 'barbarians', 'before the arrival of the Spaniards, had true dominion, public or private' (Anghie 1996: 239). In essence, Vitoria was asking a fundamental, although outrageous, question of the time - whether, ontologically, the Amerindians could be the owners of their own land and possessions. In Vitoria's understanding, there were four grounds for questioning whether the Amerindians were 'true masters before the arrival of the Spaniards.' The grounds were that the Amerindians were argued to be either: (1) sinners; (2) unbelievers; (3) madmen; or (4) insensate (Anghie 1996: 240). Vitoria (1996: 240-251) replied to each of these arguments. ${ }^{6}$ After considering each of them, he concluded that 'before arrival of the Spaniards these barbarians possessed true dominion, both in public and private affairs' (Vitoria 1991: 251). In his view, 'the barbarians undoubtedly possessed as true dominion, both public and private, as any Christians' (Vitoria 1991: 250). Consequently, 'they could not be robbed of their property either as private citizens or as princes, on the grounds that they were not true masters (ueri domini)' (Vitoria 1991: 250-251; italics in the original).

In addition, there was a fundamental element of Vitoria's reasoning that sets him apart from most of his contemporaries - he understood the Amerindians as rational humans. For him, the proof of this was that the Amerindians had, in his view, 'properly organized cities, proper marriages, magistrates and overlords (domini), laws, industries, and commerce, all of which require the use of reason. They likewise have a form (species) of religion, and they correctly apprehend things which are evident to other men, which indicates the use of reason' (Vitoria 1991: 250). The possession and use of reason is fundamental to a central element in Vitoria's thought, namely ius gentium (the law of nations). It is precisely ius gentium that 'allowed Vitoria to put at the same level of humanity both Spaniards and Indians' (Mignolo 2009: 46). Francisco de Vitoria understood ius gentium as a system of universal law whose rules could be ascertained by the use of reason (Anghie 1996: 325). Hence, ius gentium was 'what natural reason has established among all nations' (Anghie 1996: 325). For Vitoria, 'the law of nations (ius gentium) does not have the force merely of pacts or agreements between men' (Vitoria 1991: 40). Most importantly, for him, 'the whole world, which is a sense a commonwealth, has the power to enact laws which are just and convenient to all men' and those who breaking those laws are committing 'mortal crimes' (Vitoria 1991). Therefore, ius gentium should be binding 'irrespective of the local legislative convictions, beliefs, and customs, of individual communities, or indeed their place in time' (Vitoria 1991: xv). 
At a first sight, Vitoria's problematisation may seem inclusive in respect of Amerindians, as if he was seeking to protect them against the Spanish invasions. In fact, Francisco de Vitoria (1991: 251-277) did advance several counter-arguments to the most common arguments in favour of Spanish invasion, ${ }^{7}$ the later ranging from the 'right of discovery' to 'barbarians being sinners.' In doing so, he demonstrated that these arguments did not provide grounds for regarding the Spanish invasion as legitimate. Indeed, he provided a framework that essentially portrayed several situations in which the Spanish invasion and domination would be illegitimate (Vitoria 1991: 251-277).

Notwithstanding all this, a more critical analysis reveals that Vitoria did not escape the double movement evinced by Inayatullah and Blaney (2004: 10), in which 'difference becomes inferiority, and the possibility of a common humanity requires assimilation.' This is clear when one further analyses Francisco de Vitoria's thought. For instance, as noted previously, Vitoria does acknowledges that the Amerindians are possessed of reason (Vitoria 1991: 250). In fact, Anghie (1996: 325, emphasis in the original) reminds that 'it is precisely because the Indians possesses reason that are bound by ius gentium.' Hence, in Vitoria's view, both Spaniards and Amerindians were part of ius gentium, and both were obliged to abide by it. This might create the impression that Vitoria regarded Spaniards and Amerindians as equals in his problematisation. However, knowing that, on the one hand, he understood ius gentium as a system of universal law whose rules could be ascertained by the use of reason, and therefore a system established among all nations, and, on the other hand, that the Amerindians had no say in the elaboration of these rules; it is not difficult to understand this kind of system as a hierarchical one with the Amerindians at its bottom, since they were expected to abide by a set of rules that they did have any participation in its elaboration.

Even when Francisco de Vitoria acknowledged that the Amerindians were possessed with reason, he did not escape from understanding this in a hierarchic and even patronising way. For Vitoria, it could not 'be their [the Amerindians] fault if they were for so many thousands of years outside the state of salvation, since they were born in sin but did not have the use of reason to prompt them to seek baptism or the things necessary for salvation' (Vitoria 1991: 250). Therefore, 'if they seem to us insensate and slow-witted, I put it down mainly to their evil and barbarous education. Even amongst ourselves, we see many peasants (rustici) who are little different from brute animals' (Vitoria 1991: 250).

Another aspect of Vitoria's thought displaying the double movement aforementioned is his argument about the Spanish invasion. When he sought to refute arguments in favour of the Spanish invasion - usually based on the grounds that Amerindians were sinners, unbelievers, and so on - he did not, in essence, counter-argue the fundamental core of these arguments. The essence of these arguments was related to the ontology of Amerindians as being sinners, unbelievers, madmen, insensate or childish, which is hardly contested by Francisco de Vitoria. In fact, what he did was to argue that these grounds in particular were not legally valid for the Spanish domination to be considered legitimate. Therefore, Vitoria did not question the legitimacy of the Spanish conquest as such, but rather the grounds on which arguments in favour of it rested. In fact, it could even be 
argued that Vitoria actually provided the legal grounds for the legitimation of the Spanish system of commerce (Anghie 1996: 326). Therefore, Francisco de Vitoria merely had a legal concern in regards to the Spanish conquest.

Indeed, he advanced several possible grounds for the 'barbarians of the New World' to be 'passed under the rule of the Spaniards'8 (Vitoria 1991: 277). These include: (1) the spreading of the Christian religion (Vitoria 1991: 284); and (2) the 'mental incapacity of the barbarians' (Vitoria 1991: 290). As regards the first, Vitoria stated that there was reason for war 'if the barbarians [...] obstruct the Spaniards in their free propagation of the Gospel' (Vitoria 1991: 285). In his view, 'the Spaniards, after first reasoning with them to remove any cause of provocation, may preach and work for the conversion of that people even against their will, and may if necessary take up arms and declare war on them, insofar as this provides the safety and opportunity needed to preach the Gospel' (Vitoria 1991: 285, emphasis in the original). He goes as far as arguing that if Christianity could not be advanced, 'the Spaniards may lawfully conquer the territories of these people, deposing their old masters and setting up new ones' (Vitoria 1991: 285-286).

Regarding the mental capacity of Amerindians, he understood that 'there is scant difference between the barbarians and madmen; they are little or no more capable of governing themselves than madmen, or indeed than wild beasts. [...] On these grounds, they might be handed over to wiser men to govern' (Vitoria 1991: 290-291). He argued that this was permissible 'given the supposed stupidity [of the Amerindians] which those who have lived among them report of them, and which they say is much greater than that of children and madmen among other nations' (Vitoria 1991: 291). In his view, this kind of relationship would be a charitable one, since '[s] uch an argument could be supported by the requirements of charity, since barbarians are our neighbors and we are obliged to take care of their goods' (Vitoria 1991). For Vitoria, the Spaniards should 'take care' of, or actually govern, the Amerindians, since 'everything is done for the benefit and good of the barbarians, and not merely for the profit of the Spaniards' (Vitoria 1991: 291, emphasis in the original).

Consequently, the problematisation of Francisco de Vitoria is a fundamental element of the crystallisation of coloniality in international politics, since it imbricates it with the very formation of international law, making both elements, international law and coloniality, intertwined and inseparable from each other. In addition to the problematisations of Francisco de Vitoria in the early days of international law, as aforementioned, there is a second structuring problematisation that is crucial to the crystallisation of coloniality, and the double movement aforementioned, in international politics. This structuring moment is precisely the debate that became known as the Valladolid Debate (1550-1551). This debate can certainly be understood as the epicentre of the crystallisation of coloniality, and consequently the double movement aforementioned, in the international scenario from the sixteenth century onwards.

The debate was assembled by King Carlos V, and took place at the Colégio de San Gregorio in the Spanish city of Valladolid. It comprised two sessions: (1) the first from mid-August to mid-September 1550; and (2) the second from mid-April to mid-May in 
1551 (Hanke 1996: 67-68; Dussel 2014). Enrique Dussel (2013, 1993), acknowledging the crucial relevance of this debate, argues that it is at the Valladolid Debate where the 'history of modern reason had begun' (Dussel 2013: 579, footnote 278). In fact, for him, the Valladolid Debate was 'the first public and central philosophical debate of Modernity' (Dussell 2014: 32, emphasis in the original). The debate developed around a fundamental theological, legal and philosophical question, namely whether it was 'lawful for the King of Spain to wage war on the Indians, before preaching the faith to them, in order to subject them to his rule, so that afterward they may be more easily instructed in the faith' (Hanke 1996: 67). In Dussel's (2003: 32) view, this is the perennial question to Modernity: 'What right does Europe have to colonially dominate the Indies?'

In response to the this question, it was clearly perceptible two contending arguments, best vocalised by Bartolomé Las Casas, on one side, and Juan Gines de Sepulveda, on the other side. They, along with others such as Francisco de Vitoria, were engaged in a crucial debate in the $16^{\text {th }}$ century, namely to define the frontiers of what could be understood as humanity (Mignolo 2000: 283). Ultimately, the debate was about whether the Amerindians, their ultimate Other, could be regarded as humans at all, and, if so, what their position would be in the international structure of power at that time. It is true, as Maldonado-Torres (2007: 244) argues, that in '1537 the Pope declared the Amerindians as human.' This was operationalised by Pope Paul III, when in his Bull Sublimis Deus he confirmed 'the Indians' capability to understand and receive the Christian faith' (Hernandez 2001: 98). This was done in a context of arguments about the irrationality and incapacity of Amerindians, and questions about whether they could or should be educated (Hanke 1996: 17-27). However, with this Bull, the Pope actually legitimised the Spanish domination of the Americas, and incentivised Christian missionary efforts there.

Consequently, the problematisation of the relationship between the European Self and the Amerindian Other emerged putting two opposing views, represented by Gines de Sepulveda and Bartolomé Las Casas, in debate. Sepulveda 'put forward four propositions in favor of the just war against the Native Americans: first, the Indians were barbarians; second, they committed crimes against natural law; third, the Indians oppressed and killed the innocent among themselves; and fourth, they were infidels who needed to be instructed in the Christian faith' (Hernandez 2001: 100). In advancing his argumentation for a just war against the Amerindians, Gines de Sepulveda (1941) argued that it would 'always be just and in conformity with natural law that such peoples be subjected to the empire of princes and nations that are more cultured and humane, so that by their virtues and the prudence of their laws, they abandon barbarism and are subdued by a more humane life and the cult of virtue' (Sepulveda 1941: 85). Here, Sepulveda brought an Aristotelian conception of master and slave and his "legacy of differentiating peoples into "barbarian" and "civilized", and applied this dualistic differentiation to the Spanish as civilized and the Indians as barbarian' (Behr 2014: 59). Furthermore, Sepulveda understood that if they reject such an empire, it can be imposed on them by way of arms, and such a war would be just according to the declarations of natural law' (Sepulveda 1941: 85). Summarising his view, Sepulveda (1941: 87) stated that: '[i]n sum: it is just, convenient, and in conformity 
with natural law that honorable, intelligent, virtuous, and human men dominate all those who lack these qualities.'

Bartolomé de Las Casas (1992), ${ }^{9}$ in contrast, "represents the first head-on critic of Modernity" in Enrique Dussel's (2014: 27, emphasis in the original) view. Las Casas' arguments included: (1) refuting 'the claim of the superiority of Western culture, from which the barbarism of indigenous cultures was deduced'; (2) differentiating 'between [A] granting the Other (the Indian) the universal claim of his truth, [B] without ceasing to honestly affirm the very possibility of a universal validity claim in his proposal in favor of the gospel'; and (3) affirming 'the falseness of the last possible cause justifying the violence of the conquest, that of saving the victims of human sacrifice, as being against natural law and unjust from all points of view' (Dussel, 2014: 28). Bartolomé las Casas replied to each of Sepulveda's arguments. As regards Sepulveda's barbarian argument, Las Casas did not attack Aristotle's rationalisation, but questioned Sepulveda's operationalisation of the Aristotelian understanding. He argued that this rationale could not be applied to the Amerindians since they had systems of government, legal bodies that legislated their political and social life, and cultural achievements (Behr 2014: 59). Replying to Sepulveda's argument about Indian crimes against natural law, Las Casas argued that 'punishment required jurisdiction. Specifically, neither Charles V nor Pope Paul III had jurisdiction over infidels' (Hernandez 2001: 101). In essence, Las Casas argued that 'the Indians, though at a different and backward stage of human development than the Europeans, were no less rational and adept to peacefully receive the Christian faith than the peoples of the Old World' (Hernandez 2001: 100). Therefore, he understood the Amerindians as 'pagans, a group which had to be, not violently punished, but peacefully converted to Christianity' (Hernandez 2001: 103), and that ' $[\mathrm{t}]$ he Indians, an evolving human race, needed to be persuasively converted, not killed in wars of conquest, to Christianity' (Hernandez 2001: 102).

Analysing the Valladolid Debate, the very first picture that perhaps might emerge is that the debate had two completely opposing sides: (1) one actually defending the Amerindians from the Spanish brutality and vocalising its violence, represented by Las Casas, and (2) the other arguing for the war against the Amerindians, represented by Gines de Sepulveda. This portrays, for instance, Las Casas as a defender of the Amerindians, and Sepulveda arguing for their oppression. In fact, this is far from being completely inaccurate. However, a more critical understanding of the process reveals that this perception about the Valladolid Debate is a fundamentally superficial and, most importantly, misleading perception.

Having the notion of coloniality in mind, a different and essential side of the debate becomes visible. It becomes clear that the arguments advanced by Las Casas on the one hand and Sepúlveda on the other represent, respectively, both the assimilation and domination movements aforementioned. Further problematising the debate, one can clearly notice that, in fact, these two apparently opposing views agree on a fundamental aspect. The aspect that they, in essence, agree is related to the matter of difference. Both arguments agree on something that, at a first sight, might seem paradoxical - the difference 
of the Amerindians, as such, was at once completely denied and recognised hierarchically as inferior. This is the core aspect of the double movement aforementioned. Critically scrutinising both arguments, what emerges is that the real point of disagreement was only in regards to how to deal with the Amerindian difference, either pacifically or violently, and not how they understood the very essence of that difference (Dussel 1993: 77-78). Whether violently or not, both argued that, in essence, the Amerindians should be transformed.

As noted previously, it is precisely through the operationalisation of this double movement that coloniality functions in international politics. It either recognises difference, but places it in a hierarchical structure of superiority/inferiority, or fails to perceive difference, leading to assimilation. The delineation of the two structuring problematisations aforementioned seeks to evince that, precisely due to the manner in which the relationship between the European Self and the Amerindian Other is framed, they were fundamental to the crystallisation of coloniality in international politics.

Although these two structuring problematisations may seem to have historical significance only, they are still relevant to our contemporary international scenario. The double movement discussed above remains embedded in international politics. Whereas in the past coloniality, along with its double movement, was operationalised through the rhetoric of conversion to Christianity and the civilising argument, nowadays they are rendered operational through the notions of development, modernisation, democratisation and even peacebuilding directed to the periphery of the international scenario. Rather than ending with formal colonialism, the peripheral zones of the international system are still subjected to a regime of 'global coloniality' (Grosfoguel 2007: 220). Therefore, the colonial power matrix aforementioned, with its double movement of perceiving difference hierarchically and/or not considering difference at all by seeking to assimilate it, still is the power framework operational in regards to the contemporary Others of international politics.

\section{Conclusion}

This article brought visibility the notion of coloniality and its implications for understanding contemporary global politics and power relations. Most importantly, by placing the ultimate Other of Western modernity - the indigenous peoples of the Americas - at the core of the discussion, it has focused attention on two fundamental problematisations that, through the very manner in which the relationship between the European Self and the Amerindian Other was framed, crystallised coloniality in international politics. While discussing what the notion of coloniality means, the article differentiated it from colonialism and neocolonialism, and outlined some of their key characteristics. Then the article evinced that race is a fundamental element for rendering coloniality operational. In this regard, it has discussed the double movement through which coloniality functions in international politics. The first is by recognising difference, but placing it in a hierarchical structure of superiority/inferiority, and the second is by denying difference, leading to 
assimilation. Finally, the article delineated two structuring problematisations in regards to coloniality, namely the thought of Francisco de Vitoria in the very early stages of international law, and the Valladolid Debate. These problematisations are essential to the understanding of coloniality, not only because they demonstrate the double movement through which coloniality is rendered operational, but also because they are fundamental to its crystallisation in international politics. Consequently, being coloniality the darker side of modernity, an international reality such as ours, that is anchored on nothing but modern pillars, cannot escape from having the coloniality as its fundamental element, reproducing its double movement, and maintaining a colonial power matrix directed to the margins of the global population. It is precisely through the effort of bringing attention to the notion of coloniality, and its crystallisation in international politics, that one can not only perceive how it is rendered operational, see that it is still alive in the current international reality, but also seek to overcome this still structuring condition of the international politics.

\section{Notes}

1 Researchers who have successfully done this include Cornway and Sing (2011), Blaney and Tickner (2017), Jackson (2017), Pasha (2011), Persaud (2015), Rojas (2007, 2016), Sajed (2013), Tickner and Blaney (2013) and Shilliam (2015).

2 For a discussion regarding the absence of race within the discussions of IR, see Anievas et al (2015).

3 For a discussion of time and international relations, see for instance, Hutchings and Kimberly (2008), Solomon and Ty (2014), Agathangelou and Killian (2016) and Hom et al (2016).

4 For an examination of space and international processes, such as post-conflict reconstruction efforts, see Björkdahl and Buckley-Zistel (2016) and Björkdahl and Kappler (2017).

5 For a genealogy of how difference and otherness are problematised in Western thought, see for instance Behr (2014). For an examination of the matter of difference in international relations, see Inayatullah and Blaney (2004).

6 For a detailed account of each counter-argument, see Vitoria (1991: 240-251).

7 For an account of these counter-arguments, see Vitoria (1991: 251-277).

8 For a comprehensive account of these grounds, see Vitoria (1991: 277-292).

9 For a biographical account of Las Casas thought, see for instance Wagner and Parish (1967).

\section{References}

Abernethy, D B. 2000. The Dynamics of Global Dominance. New Haven: Yale University Press.

Agathangelou, A M and K D Killian (eds). 2016. Time, Temporality and Violence in International Relations: (De)Fatalizing the Present, Forging Radical Alternatives. London: Routledge.

Anghie, A. 1996. 'Francisco de Vitoria and the Colonial Origins of International Law.' Social \& Legal Studies 5 (3): 321-336.

2004. Imperialism, Sovereignty and the Making of International Law. Cambridge: Cambridge University Press.

Anievas, A, N Manchanda and R Nivi (eds). 2015. Race and Racism in International Relations: Confronting the Global Colour Line. New York: Routledge. 
Ashworth, L. 2002. 'Did the Realist-Idealist Great Debate Really Happen? A Revisionist History of International Relations.' International Relations 16 (1): 33-51.

Ballestrin, L. 2013. 'América Latina e o Giro Decolonial.' Revista Brasileira de Ciência Política 11: 89-117.

Behr, H. 2014. Politics of Difference: Epistemologies of Peace. London: Routledge.

Björkdahl, A and S Buckley-Zistel (eds). 2016. Spatializing Peace and Conflict: Mapping the Production of Places, Sites and Scales of Violence. London: Palgrave.

Björkdahl, A and S Kappler (eds). 2017. Peacebuilding and Spatial Transformation: Peace, Space and Place. London: Routledge.

Blaney, D and A Tickner. 2017. 'Worlding, Ontological Politics and the Possibility of a Decolonial IR.' Millennium: Journal of International Studies 00(0): 1-19.

Boucher, D. 2009. The Limits of Ethics in International Relations: Natural Law, Natural Rights and Human Rights in Transition. New York: Oxford University Press.

Bush, B. 2006. Imperialism and Postcolonialism. Harlow: Pearson Longman.

Casas, B de las. 1992. In Defense of the Indians. DeKalb: Northern Illinois University Press.

Castro-Gómez, S. 2010. La Hybris del Punto Cero. Ciencia, raza e ilustración en la Nueva Granada (1750-1816). Bogotá: Editorial Pontificia Universidad Javeriana, Instituto de Estudios Sociales y Culturales Pensar.

Césaire, A. 2000. Discourse on Colonialism. New York: Monthly Review Press.

Chakrabarty, D. 2008. Provincializing Europe. Postcolonial Thought and Historical Difference. Princeton: Princeton University Press.

Chaterjee, P. 1993. The Nation and Its Fragments: Colonial and Postcolonial Histories. Princeton: Princeton University Press.

Cornway, J and Jakeet Sing. 2011. 'Radical Democracy in Global Perspective: notes from the pluriverse.' Third World Quarterly 32 (4): 689-706.

Darby, P. 2004. 'Pursuing the political: a postcolonial Rethinking of International Relations.' Millennium: Journal of International Studies 33 (1): 1-32.

De La Cadena, M. 2000. The Politics of Race and Culture in Cuzco, Peru, 1919-1991. Durham: Duke University Press.

Dussel, E. 1993. 1492 El Encubriminento del Otro: Hacia el Origen del 'Mito de La Modernidad'. La Paz: Plural Editores.

2013. Ethics of Liberation: In the Age of Globalisation and Exclusion. Durham: Duke University Press.

2014. 'Anti-Cartesian meditations: on the orign of the philosophical anti-discourse of modernity.' Journal for Cultural and Religious Theory 13 (1): 11-52.

Fabian, J. 1983. Time and the Other: How Anthropology Makes Its Object. New York: Columbia University Press.

Fanon, F. 2004. The Wretched of the Earth. New York: Grove Press.

Fernandes, J P T. 2011. Teorias das Relações Internacionais: Da Abordagem Clássica ao Debate Pós-Positivista. Coimbra: Editora Almedina.

Foucault, M. 1979. A Microfísica do Poder. Transl. Roberto Machado. Rio de Janeiro: Graal. 
Gallagher, J and R Robinson. 1953. 'The Imperialism of Free Trade.' The Economic History Review $6(1): 1-25$.

Grosfoguel, R. 2007. 'The epistemic decolonial turn: beyond political-economy paradigms.' Cultural Studies 21 (2): 211-223.

Hanke, L. 1996. All Mankind is One: A Study of the Disputation Between Bartolomé de Las Casas and Juan Ginés de Sepúlveda in 1550 on the Intellectual and Religious Capacity of the American Indians. DeKalb: Northern Illinois University Press.

Helliwell, C and B Hindess. 2005. 'The temporalizing of difference.' Ethnicities 5 (3): 414-418.

Hernandez, B L. 2001. 'The Las Casas-Sepúlveda controversy: 1550-1551.' Ex Post Facto: Journal of History Students at San Francisco State University X: 95-104.

Hom, A, C Mcintosh, A Mckay and L Stockdale (eds). 2016. Time, Temporality and Global Politics. Bristol: E-IR Publishing.

Hudson, K A. 2009. Justice, Intervention and Force in International Relations: Reassessing just war theory in the $21^{\text {st }}$ century. New York: Routledge.

Hutchings, K. 2008. Time and World Politics: Thinking the Present. Manchester: Manchester University Press.

Inayatullah, N. 2008. 'Why do some people think they know what is good for others?' In J Edkin and M Zehfus (eds), Global Politics: A New Introduction. London: Routledge, pp. 344-369.

Inayatullah, N and D L Blaney. 2004. International Relations and the Problem of Difference. New York: Routledge.

Jackson, M (ed). 2017. Coloniality, Ontology, and the Question of the Posthuman. New York: Routledge.

Jahn, B. 2000. The Cultural Construction of the International Relations: The Invention of the State of Nature. New York: Palgrave.

Kelly, M G E. 2009. The Political Philosophy of Michel Foucault. New York: Routledge.

Kennedy, D. 1986. 'Primitive legal scholarship.' Harvard International Law Journal 27 (1): 1-98.

Maldonado-Torres, N. 2007. 'On the coloniality of being: contributions to the development of a concept.' Cultural Studies 21 (2-3): 240-273.

Marks, J. 1994. Human Biodiversity: Genes, Race, and History. New York: Aldyne de Gruyter.

Memmi, A. 1991. The Colonizer and the Colonized. Boston: Beacon Press.

Mignolo, W D. 2000. Local Histories/Global Designs - Coloniality, Subaltern Knownledges, and Border Thinking. Princeton: Princeton University Press.

2009. 'Coloniality: the darker side of modernity'. In S Breitwisser (ed), Modernologies. Contemporary Artists Researching Modernity and Modernism. Barcelona: MACBA, pp. 39-49.

Mignolo, W D. 2010. Desobediencia Epistémica: Retórica de la Modernidade, Lógica de la Colonialidad, y Gramática de la Descolonialidad. Buenos Aires: Ediciones del Signo.

Nkrumah, K. 1965. Neo-Colonialism: The Last Stage of Imperialism. London: Heinemann.

Nandy, A. 1983. The Intimate Enemy: Loss and Recovery of Self under Colonialism. Oxford: Oxford University Press. 
Ortega, M C. 2016. 'Vitoria and the universalist conception of International Relations.' In I Clark and I B Neumann (eds), Classical Theories of International Relations. London: Macmillan Press, pp. $99-118$

Pasha, M K. 2011. 'Untimely reflections.' In R Shilliam (ed), International Relations and Non-Western Thought: imperialism, colonialism, and investigations of global modernity. London: Routledge, pp. 217-226.

Persaud, R. 2015. 'Race, de-coloniality and International Relations.' Alternatives 40: 2.

Pratt, M L. 1992. Imperial Eyes: Travel Writing and Transculturation. New York: Routledge.

Quijano, A. 1992a. 'Colonialidad y Modernidad/Racionalidad.' In H Bonilla (ed), Los Conquistados: 1492 y la Población Indígena de las Américas. Quito: Tercer Mundo Editores, FLACSO, Libri Mundi, pp. 437-448.

1992b. ‘Raza, Etnia y Nación: Cuestiones Abiertas.' In R Forgues (ed), José Carlos Mariátegui y Europa. El Otro Aspecto del Descubrimiento. Lima: Amauta.

. A. 2000a. 'Colonialidad del Poder, Eurocentrismo y América Latina.' In E Lander (ed), La Colonialidad del Saber: Eurocentrismo y Ciencias Sociales. Perspectivas Latinoamericanas. Buenos Aires: CLACSO, pp. 201-246.

.2000b. 'Coloniality of power, Eurocentrism, and Latin America' Nepantla: Views from South 1 (3): 533-580.

2007. 'Coloniality and Modernity/Rationality'. Cultural Studies 21 (2-3): 168-178.

Rabinow, P (ed). 1984. The Foucault Reader. London: Penguin Books.

Rojas, C. 2007. 'International Political Economy/Development Otherwise.' Globalisations 4 (4): 573 587.

2016. 'Contesting the colonial logics of the international: toward a relational politics for the pluriverse.' International Political Sociology 10: 369-382.

Sajed, A. 2013. Postcolonial Encounters in International Relations: The Politics of Transgression in the Maghreb. New York: Routledge.

Scott, J B. 2013. The Spanish Origin of International Law: Francisco de Vitoria and his Law of Nations. New Jersey: The Lawbook Exchange.

Sepúlveda, J G de. 1941. Tratado sobre las Justas Causas de la Guerra contra los Indios. Mexico City: Fondo de Cultura Económica.

Solomon, T. 2014. 'Time and subjectivity in world politics.' International Studies Quarterly 58 (4): 671-681.

Shilliam, R. 2015. The Black Pacific: Anti-Colonial Struggles and Oceanic Connections. London: Bloomsbury.

Tickner, A B and D L Blaney (eds). 2013. Claiming the International. New York: Routledge.

Todorov, T. 1984. The Conquest of America: The Question of the Other. New York: Harper and Row.

Twinam, A. 2009. 'Purchasing whiteness: conversations on the essence of Pardo-ness and Mulatoness at the end of Empire.' In A B Fisher and M D O'Hara (eds), Imperial Subjects: Race and Identity in Colonial Latin America. Durham: Duke University Press.

Vitoria, F de. 1991. Political Writtings. Cambridge: Cambridge University Press. 
Wagner, H R and H R Parish. 1967. The Life and Writings of Bartolomé de Las Casas. New Mexico: The University of New Mexico Press.

Walker, R B J. 1993. Inside/outside: International Relations as Political Theory. Cambridge: Cambridge University Press.

Wallerstein, I. 1974. The Modern World-System - Capitalist Agriculture and the Origins of the European World-Economy in the Sixteenth Century. New York: Academic Press, Inc.

1996. 'The inter-state structure of the modern world-system.' In S Smith, K Booth and M Zalewski (eds), International Theory: Positivism and Beyond. Cambridge: Cambridge University Press, pp. 87-107.

2004. World-Systems Analysis - An Introduction. Durham and London: Duke University Press.

Wilson, P. 1998. 'The myth of “The First Great Debate." Review of International Studies 24 (5): 1-15.

Young, R J C. 2001. Postcolonialism: An Historical Introduction. Malden: Blackwell.

\section{About the authors}

Ramon Blanco holds a Ph.D. in International Relations from the University of Coimbra (Portugal), and is an Adjunct Professor at the Federal University of Latin-American Integration (UNILA), where he coordinates the Peace Studies Research Group and the Chair in Peace Studies. He is also a Permanent Professor of the Graduate Program in International Relations of UNILA (PPGRI-UNILA) and the Graduate Program in Political Science of the Federal University of Paraná (PPGCP-UFPR). He thanks UNILA for the financial support enabling this research under the following funding instruments: PRPPG No 109/2017, PRPPG No 58/2018, PRPPG No 110/2018 and PRPPG No 154/2018.

Ana Carolina Teixeira Delgado is an Assistant Professor at the Federal University of Latin American Integration (UNILA), where she is also a member of the Graduate Program in International Relations (PPGRI-UNILA). She holds a Ph.D. in International Relations from PUC-Rio, where she has also lectured. She has taught courses on Actors of Emerging Global Civil Society; International Relations of Latin America; State, Politics \& Development in Latin America; Gender; and Indigenous Peoples in IR. She has worked as Research Assistant at the BRICS Policy Centr (BPC) and as Assistant Coordinator of the South American Political Observatory (OPSA). Her dissertation research was on decolonisation and internal colonialism in Bolivia, where she stayed for a year under the supervision of Luis Tapia. 


\section{Problematizando o Outro Absoluto da Modernidade: A Cristalização da Colonialidade na Política Internacional}

Resumo: Este artigo examina um elemento essencial para a operacionalização das relações de poder que sustentam a política internacional, a saber, a colonialidade. Ele delineia a colonialidade da política internacional e elucida, por um lado, os aspectos fundamentais de sua operacionalização e, por outro lado, a sua cristalização no cenário internacional. $\mathrm{O}$ artigo está estruturado em três seções. Em primeiro lugar, ele explora o significado de colonialidade e esboça suas características fundamentais. Em seguida, ele delineia um elemento operativo crucial da colonialidade, a ideia de raça, e o duplo movimento através do qual a colonialidade se torna operacional - a colonização do tempo e do espaço. Finalmente, o artigo analisa duas problematizações estruturantes que foram fundamentais para a cristalização da colonialidade na política internacional - os pensamentos de Francisco de Vitoria e o Debate de Valladolid. O artigo argumenta que o próprio modo como estas problematizações enquadraram a relação entre o Eu Europeu e o Outro absoluto da modernidade ocidental - os povos indígenas das Américas - cristalizou a colonialidade na política internacional.

Palavras-chave: colonialidade; política internacional; matriz colonial de poder; Francisco de Vitoria; Debate de Valladolid.

Received on 6 February 2018, and approved for publication on 1 April 2019. 